\title{
Influence of cytological stains on comparative genomic hybridization analysis for DNA extracted from cytological smears
}

\author{
SHIGETO KAWAUCHI ${ }^{1}$, SAYAKA SUGIMOTO ${ }^{1,2}$, XU-PING LIU ${ }^{1}$, KENZO IKEMOTO ${ }^{1}$, \\ TOMOKO FURUYA $^{1}$, MUTSUO TAKAHASHI ${ }^{2}$ and KOHSUKE SASAKI ${ }^{1}$ \\ Departments of ${ }^{1}$ Pathology and ${ }^{2}$ Health Sciences, Yamaguchi University School of Medicine, \\ Yamaguchi 755-8505, Japan
}

Received April 16, 2007; Accepted July 9, 2007

\begin{abstract}
In the present study, we investigated the influence of cytological stains in analyzing DNA extracted from cytological slides by comparative genomic hybridization (CGH). Multiple imprint cytological slides were prepared for fresh-frozen breast cancer tissue samples and the slides were stained by three staining methods for each sample. Under microscopic observation, cancer cells were selectively microdissected from the slides and forwarded to DNA extraction, whole genome amplification, and CGH analysis. $\mathrm{CGH}$ was successfully performed for all methylgreenstained and May-Grunwald-Giemsa (MGG)-stained cytological smear slides, but for two Papanicolaou (PAP)stained slides. The number of chromosomal imbalances detected were 5-10 in methylgreen-stained slides and 5-9 in MGG-stained slides. The chromosomal imbalances resemble each other between methylgreen-stained and MGG-stained slides. The present study indicates that the MGG stain is preferred to the PAP stain for the purpose of cytogenetical analysis by CGH for DNA extracted from cytological smear slides.
\end{abstract}

\section{Introduction}

Cytological examination, as shown by its popular use in the screening programs for uterine-cervical or lung cancer, developed as a method to detect malignant cells based on morphological observation. Over the years, however, cytopathology laboratories have experienced dramatic changes in the types and numbers of specimens submitted for cytological evaluation (1). In clinical medical practice, the cytological examination is expected to have ever higher

Correspondence to: Dr Shigeto Kawauchi, Department of Pathology, Yamaguchi University School of Medicine, 1-1-1 Minamikogushi, Ube, Yamaguchi 755-8505, Japan

E-mail: shig@yamaguchi-u.ac.jp

Key words: breast cancer, cytology, May-Grunwald-Giemsa stain, degenerate oligonucleotide-primed PCR, comparative genomic hybridization quality and accuracy. When histopathological diagnosis is not available for some reasons, cytological diagnosis may be regarded as the final diagnosis and treatment decisions may be made based on it. Thus, it is reasonable that techniques improving the diagnostic accuracy and quality should be applied to diagnostic cytology.

Cancer arises as a result of accumulation of various genetic and epigenetic abnormalities (2). Cytogenetical analysis of individual malignancy is thus thought to be essentially important for recently advocated evidence-based or personalized medicine. For this purpose, molecularcytogenetical techniques such as comparative genomic hybridization ( $\mathrm{CGH}$ ) (3), have been developed. $\mathrm{CGH}$ measures the ratio between fluorescence-labeled sample DNA and differently fluorescence-labeled normal reference DNA, which are simultaneously co-hybridized on normal metaphase chromosome spreads (4) or array of chromosome DNA segments (5). A computer-based analysis of fluorescence pattern of hybridized chromosomes reveals loss, gain, or amplification of chromosome DNA segments. Thus, in a single hybridization, $\mathrm{CGH}$ enables to detect chromosome imbalances across the whole genome and to screen oncogenes and tumor suppressor genes associated with tumorigenesis and tumor progression.

Differing from classical karyotypic analysis, $\mathrm{CGH}$ can be applied to various specimens, such as cell lines, short-term cultured cells, blood specimens, fresh-frozen tissues, and even archival formalin-fixed paraffin-embedded tissues (3). This broad applicability is one of the reasons why CGH has been widely used in the field of cancer cytogenetical research. Nonetheless, it is sometimes difficult to obtain a sufficient amount of sample DNA, for example, unexpected degradation of sample DNA and unavailability of surgical procedure for tumor sampling. In such situations, cytological smears could be used as an alternative source of sample DNA (6-10).

We have developed $\mathrm{CGH}$ techniques to analyze sample DNA extracted from cytological slides $(9,10)$. However, several problematic factors exist that adversely influence the CGH results, such as cytological stains and mounting media. In the present study, we describe our $\mathrm{CGH}$ techniques to analyze DNA extracted from cytological slides and further examined the influence of cytological stains on $\mathrm{CGH}$. 


\section{Materials and methods}

Materials and DNA extraction. Seven surgically-resected fresh-frozen breast carcinoma tissues were selected from the department of pathology files of the Yamaguchi University School of Medicine and affiliated hospitals. Cytological imprint slides were prepared by touching breast carcinoma tissue specimens to silane-coated glass slides and air-dried or fixed in $95 \%$ ethanol at room temperature. More than three slides were prepared for each carcinoma tissue specimen. The cytological imprint slides were stained by the standard Papanicolaou (PAP), May-Grunwald-Giemsa (MGG), and the methylgreen methods (1). The slides were then observed light-microscopically without mounting. Approximate 100-300 carcinoma cells were microdissected from each slide using a 28 -gauge needle and collected into a plastic tube. The microdissected carcinoma cell aggregates were incubated with $40 \mu 1$ of 1X Ex Tag PCR buffer (Takara, Tokyo, Japan) containing $0.5 \%$ Tween-20 and $0.5 \mathrm{mg} / \mathrm{ml}$ proteinase $\mathrm{K}$ at $55^{\circ} \mathrm{C}$ for 3 days. After incubation, proteinase $\mathrm{K}$ was inactivated by heating at $95^{\circ} \mathrm{C}$ for $10 \mathrm{~min}$.

Whole genome DNA amplification. Extracted DNA was amplified by two-step degenerate oligonucleotide-primed polymerase chain reaction (DOP PCR) (11). Sample DNA lysate $(1.0 \mu \mathrm{l})$ was mixed with $0.4 \mu \mathrm{l}$ of $200 \mu \mathrm{M} \mathrm{dNTP}$ mixture, $0.5 \mu 1$ of $10 \mu \mathrm{M}$ DOP PCR primer, $0.7 \mu 1$ of thermosequenase (Amersham, Tokyo, Japan), $0.5 \mu 1$ of $5 \mathrm{x}$ thermosequenase reaction buffer (Amersham), and $2.6 \mu 1$ of distilled water. The mixture was then forwarded to the first DOP PCR. The reaction condition of the first DOP PCR was initial denaturation at $94^{\circ} \mathrm{C}$ for $10 \mathrm{~min}$ and 5 cycles of denaturation at $94^{\circ} \mathrm{C}$ for $1 \mathrm{~min}$, annealing at $25^{\circ} \mathrm{C}$ for $1 \mathrm{~min}$, and extension at $74^{\circ} \mathrm{C}$ for $2 \mathrm{~min}$. In the second DOP PCR, a total volume of the first DOP PCR product was mixed with a $44 \mu 1$ of reaction solution containing $4.5 \mu 1$ of $10 \mathrm{X}$ Ex Taq PCR buffer (Takara, Tokyo, Japan), $3.6 \mu 1$ of dNTP mixture (Takara), $1.0 \mu \mathrm{l}$ of $100 \mu \mathrm{M}$ DOP PCR primer, $0.5 \mu \mathrm{l}$ of Ex Taq polymerase (Takara), and $34.4 \mu 1$ of distilled water. Reaction condition of the second PCR was initial denaturation at $94^{\circ} \mathrm{C}$ for $10 \mathrm{~min}$, and 32 cycles of denaturation at $94^{\circ} \mathrm{C}$ for $1 \mathrm{~min}$, annealing at $56^{\circ} \mathrm{C}$ for $1 \mathrm{~min}$, and extension at $72^{\circ} \mathrm{C}$ for $3 \mathrm{~min}$, followed by the final extension at $72^{\circ} \mathrm{C}$ for $10 \mathrm{~min}$. DNA extracted from normal female lymphocytes was also amplified by DOP PCR and served as reference DNA.

Amplified sample and reference DNAs were electrophoresed on a $1.5 \%$ agarose gel and stained with ethidium bromide to estimate satisfactory amplification and availability to the following fluorescence labeling reaction.

Fluorescence labeling. DOP PCR-amplified sample DNA product $(1.0 \mu \mathrm{l})$ was mixed with $1.0 \mu \mathrm{l}$ of $10 \mathrm{X}$ Ex Tag PCR buffer, $1.0 \mu 1$ of 10X PCR-labeling dNTP mixture (11), $0.4 \mu 1$ of $100 \mu \mathrm{M}$ DOP primer, $0.5 \mathrm{mg}$ of spectrum-green-11-dUTP (Vysis, Downers Grove, IL, USA), and 1.0 U of Ex Tag polymerase. PCR condition was initial denaturation at $95^{\circ} \mathrm{C}$ for 5 min, 25 cycles of denaturation at $95^{\circ} \mathrm{C}$ for $1 \mathrm{~min}$, annealing at $56^{\circ} \mathrm{C}$ for $1 \mathrm{~min}$, and extension at $72^{\circ} \mathrm{C}$ for $2 \mathrm{~min}$, followed by final extension at $72^{\circ} \mathrm{C}$ for $10 \mathrm{~min}$. DOP PCR-amplified reference DNA product was also labeled with spectrumorange-11-dUTP (Vysis) as described above.

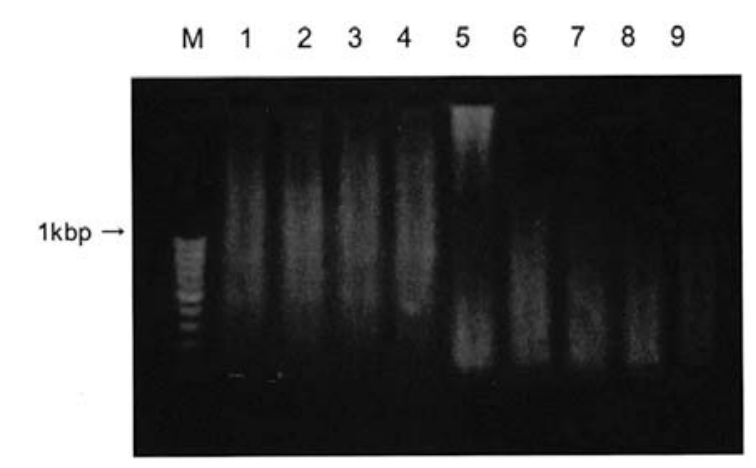

Figure 1. Electrophoresis of amplified DNA by degenerate oligonucleotideprimed polymerase chain reaction (DOP PCR). (6-9) Amplified DNA from methylgreen-stained and MGG-stained cytological slides were observed as smears ranging from $100 \mathrm{bp}$ to $1.5 \mathrm{kbp}$ in size. (5) Amplified DNA from Papanicolaou-stained cytological slide tends to distribute in a full range of the electrophoresis gel. M, size marker; (1-4) Amplified reference DNA (normal female lymphocyte); (5) Amplified DNA from Papanicolaoustained cytological slide; $(6,7)$ Amplified DNA from May-GrunwaldGiemsa-stained cytological slides; $(8,9)$ Amplified DNA from methylgreenstained cytological slides.

$C G H$. Spectrum-green-labeled sample DNA (10 $\mu 1), 10 \mu 1$ of spectrum-orange-labeled reference DNA, and $30 \mu \mathrm{g}$ of human Cot-1 DNA (Vysis) were precipitated with ethanol and dissolved in hybridization buffer composed of $50 \%$ formamide and $10 \%$ dextran sulfate. The probe mixture was heat-denatured and hybridized onto denatured normal lymphocyte metaphase chromosomes on a CGH target slide (Vysis). After hybridization, the target slide was washed and counterstained with 4,6-diamino-2-phenylinodole in antifade solution (Vysis).

Color images of the hybridized metaphase chromosomes were captured and the ratios of fluorescence intensity along chromosomes were analyzed using a Quips XL software program (Vysis). Chromosome DNA copy number aberration (CNA) was defined as a sample-to-reference DNA fluorescence ratio. Loss, gain, and amplification of sample DNA copy number were considered when CNAs were $<0.8,>1.2$, and $>1.4$, respectively (9). CNA was not scored at or near centromeres.

\section{Results}

Electrophoresis. DNA samples that were extracted from the imprint cytological slides and amplified by DOP PCR were electrophoresed on a $2.0 \%$ agarose gel. DNA samples that were extracted and amplified from methylgreen-stained and MGG-stained slides were observed as smears ranging from $100 \mathrm{bp}$ to $1.5 \mathrm{kbp}$ in size (Fig. 1). DNA samples from PAPstained slides tended to distribute in a full range of the gel.

CGH. CGH analysis was possible in 7 of 7 MGG-stained imprint cytological slides (100\%), 7 of 7 methylgreen-stained slides $(100 \%)$, and 2 of 7 PAP-stained slides (29\%). In CGH for DNA extracted from PAP-stained slides, the intensity of spectrum-green fluorescence conjugated with sample DNA was too low to analyze satisfactorily in 5 of $7 \mathrm{CGH}$ target slides. The intensity of spectrum-orange fluorescence conjugated with reference DNA was sufficiently high for analysis 
A

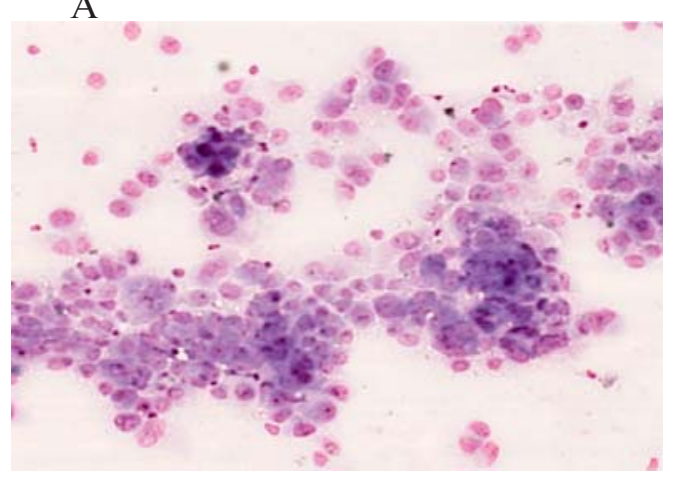

$\mathrm{B}$

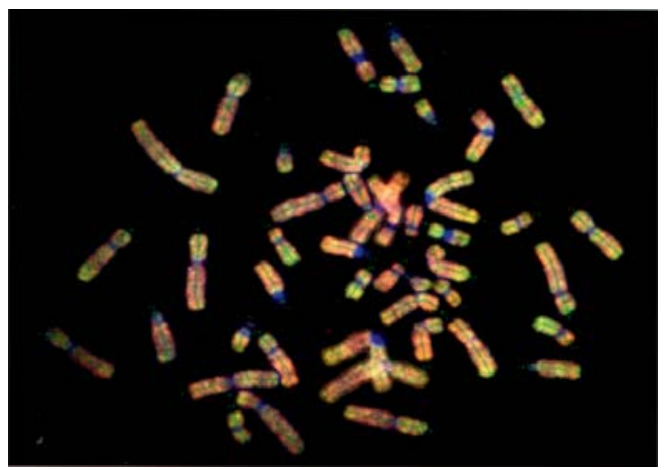

$\mathrm{C}$

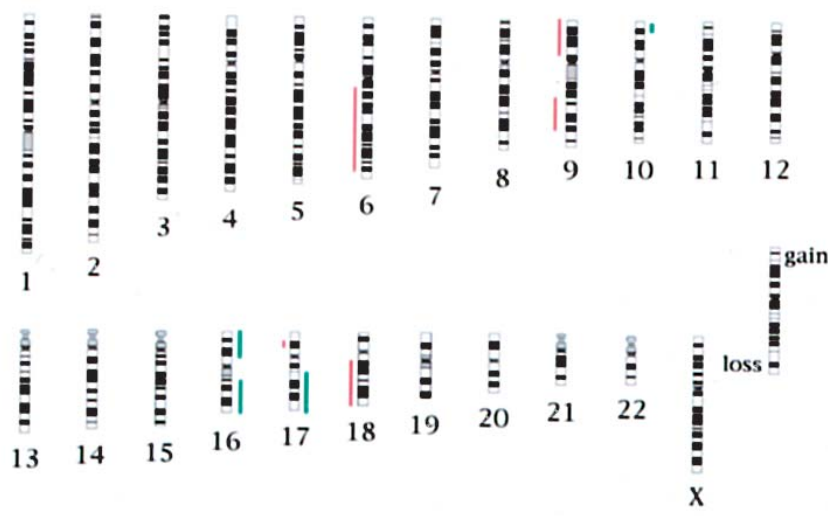

Figure 2. Case no. 2. (A) Imprint cytological slide of invasive ductal carcinoma of the breast stained by the May-Grunwald-Giemsa technique. (B) Fluorescence image of metaphase chromosomes in comparative genomic hybridization for DNA extracted from May-Grunwald-Giemsa-stained imprint cytological slide. Green, red, and blue fluorescence is observed equivalently with regional differences. (C) Result of comparative genomic hybridization for DNA extracted from imprint cytological slide. The rightsided green lines represent DNA copy number gains and amplifications, and the left-sided red lines losses.

in all the CGH target slides. In CGH for DNA extracted from MGG-stained and methylgreen-stained slides, the intensity of spectrum-green and spectrum-orange fluorescence was sufficiently high for analysis (Fig. 2).
The numbers of CNA detected were 4-9 (mean 6.1) in MGG-stained cytological samples, and 5-10 (mean 6.9) in methylgreen-stained samples (Table I). The numerical differences in CANs detected between MGG-stained and methylgreen-stained cytological samples were 0-2 (mean 0.9 ). The CNAs detected were the same between MGGstained and methylgreen-stained cytological samples in one of 7 breast cancer specimens (Table I, no. 4). Furthermore, in the remaining 6 specimens, the CANs resembled with each other between MGG-stained and methylgreen-stained cytological slides. The sensitivity of the CNAs detected from MGG-stained cytological slides for those from methylgreenstained slides was $75-100 \%$ (mean $83.4 \%$ ).

\section{Discussion}

To the best of our knowledge, Aubele et al first analyzed sample DNA extracted from uterine-cervical smear slides by CGH (6). Taking their result and others $(7,8)$ into consideration, we have developed CGH techniques combined with microdissection and whole genome amplification for sample DNA extracted from cytological smears $(9,10)$. However, several problematic factors exist, such as cytological stains and mounting media, influencing the $\mathrm{CGH}$ results. The present study was designed to investigate the influence of cytological stains on CGH for DNA extracted from cytological slides.

It is known that the availability and reliability of DOP PCR CGH depends on the quality of sample DNA for whole genome amplification and fluorescence labeling. Methylgreen stain is widely used as counterstain in the DNA extraction from sample tissue sections because DNA extracted from a methylgreen-stained tissue section is better in quality than that extracted from tissue sections stained by other methods (11). In the present study, DNA extracted from methylgreen-stained cytological slides showed the best quality in whole genome DNA amplification and following CGH among the cytological stains examined. However, methylgreen stain is usually poor in the observed cellular structure, thus, considered to be inappropriate for use in diagnostic cytology.

The PAP stain is most widely used for the purpose of diagnostic cytology. In the present study, 5 of 7 DNA samples extracted from PAP-stained cytological slides failed to show sufficient fluorescence signals on the hybridized metaphase chromosomes. Failed CGH might be due to hematoxylin and heavy metal ions such as phosphotungstic acid in the staining solution, which were reported to disturb DOP PCR amplification (11).

Although the MGG stain is poor in cytoplasmic transparency comparing to the PAP stain, the MGG stain has been used in the stain of air-dried cytological preparations including aspiration biopsy, blood, and bone marrow samples. In the present study, DNA samples extracted from the MGG-stained cytological slides were better in the DNA amplification and fluorescence labeling than those from the PAP-stained slides. The CGH results of the MGG-stained cytological slides were almost comparable to those of the methylgreen-stained slides, and the CNAs detected from the MGG-stained and methylgreen-stained cytological slides resemble each other. 
Table I. Chromosomal imbalances detected by DOP PCR CGH for DNA extracted from imprint cytological smears of breast cancer specimen.

Methylgreen stain

\begin{tabular}{|c|c|c|}
\hline \multirow[b]{2}{*}{ Specimens (no.) } & \multirow[b]{2}{*}{ Gain and amplification } & \multirow[b]{2}{*}{ Loss } \\
\hline & & \\
\hline 1 & $1 q, 3 q 22-q 23,8 q 23-q t e r, 16 p$ & $9 p, 9 q 21-q 33,11 q 23-q t e r, 14 q$ \\
\hline 2 & 10p14-pter, 16p, 16q12-qter, 17q21-qter, Xq13-q21 & 3p12-p21, 6q13-q25, 9p13-pter, 9q22-q32, 18q12-pter \\
\hline 3 & 1q32-qter, 4p & 10p12-p14, 10q22-qter, 11q14-q24, 18q22-qter \\
\hline 4 & $13 q 21-q$ ter & 3p14-24, 10q25-q26, 11p14-p15, 11q23-qter \\
\hline 5 & 2p22-p24, 2q36-qter, 5q14-q22 & 7p13-p21,8q24, 16q23-qter \\
\hline 6 & 1q41-qter, $16 \mathrm{p}$ & 3p14-p24, 9p13-p21, 9q21-qter, 11q \\
\hline 7 & 2q36-qter, 5q & 3p12-p21, 6q13-q25, 9p13-pter, 9q22 \\
\hline
\end{tabular}

\begin{tabular}{|c|c|c|}
\hline \multirow[b]{2}{*}{ Specimens (no.) } & \multicolumn{2}{|c|}{ May-Grunwald-Giemsa stain } \\
\hline & Gain and amplification & Loss \\
\hline 1 & $1 q, 3 q 22-q 23,16 p$ & 9p, 9q21-qter, 11q23-qter \\
\hline 2 & 10p14-pter, 16p, 16q12-qter, 17q21-qter & 6q13-q25, 9p13-p24, 9q22-q32, 17p12, 18q12-qter \\
\hline 3 & 1q32-qter, $4 \mathrm{p}$ & 10p12-p14, 10q22-q26, 11p12-p15, 11q13-qter, 18q22-qter \\
\hline 4 & $13 q 21-q$ ter & 3p14-p24, 10q25-qter, 11p14-p15, 11q23-qter \\
\hline 5 & $2 \mathrm{p} 22-\mathrm{p} 24,5 \mathrm{q} 14-\mathrm{q} 22$ & 7p12-p14, 8p22-pter, 8q24, 16q23-qter \\
\hline 6 & 1q41-qter, $16 \mathrm{p}$ & 3p14-p24, 9p13-p21, 9q21-qter, 11q23-qter \\
\hline 7 & 2q36-qter & 3p12-p21, 6q13-q25, 9p12 \\
\hline
\end{tabular}

Papanicolaou stain

\begin{tabular}{llll}
\cline { 3 - 3 } Specimens (no.) & \multicolumn{1}{c}{ Gain and amplification } & Loss \\
\hline 1 & $1 \mathrm{q}, 16 \mathrm{p}$ & $9 \mathrm{p}, 11 \mathrm{q} 23,14 \mathrm{q}$ \\
2 & na & na \\
3 & $1 \mathrm{q} 32-\mathrm{qter}$ & $10 \mathrm{p} 12-\mathrm{p} 14,10 \mathrm{q} 21-\mathrm{qter}, 11 \mathrm{q}$ \\
4 & na & na \\
5 & na & na \\
6 & na & na \\
7 & na & na
\end{tabular}

DOP PCR CGH, degenerate ologonucleotide-primed polymerase chain reaction comparative genomic hybridization. na, not analyzable.

Taking these results into consideration, the MGG stain is preferred to the PAP stain as a cytological staining technique for the purpose of CGH analysis of sample DNA extracted from cytological slides.

Furthermore, in our preliminary study, it was shown that a kind of cytological mounting media severely disturbed the whole genome DNA amplification and fluorescence labeling by DOP PCR (data not shown). Although this is thought to be another important problem in analyzing DNA extracted from cytological slides, the influence of cytological mounting media on CGH performance has rarely been studied (12). Thus, in the present study, the stained cytological slides were forwarded to DNA extraction without mounting to avoid the influence of mounting media. Further studies will be necessary to clarify the influence of cytological compound medium on $\mathrm{CGH}$.
In summary, we described our CGH technique to analyze DNA extracted from cytological slides and examined the influence of cytological stains on the CGH results. The MGG stain is preferred to the PAP stain for the purpose of $\mathrm{CGH}$ analysis of DNA extracted from cytological smears.

\section{References}

1. Bares CE: Laboratory techniques. In: Koss's Diagnostic Cytology and its Histopathologic Bases. Koss LG and Melamed MR (eds). 5th edition. Lippicott Williams \& Wilkins, Philadelphia pp1570-1634, 2005.

2. Perkins AS and Stern DF: Molecular biology of cancer. In: Rosenberg Cancer: Principles and Practices of Oncology. De Vita VT Jr and Hellman SA (eds). 5th edition. Lippicott-Raven, Philadelphia, pp79-102, 1997.

3. Kawauchi S, Oga A and Sasaki K: Comparative genomic hybridization in cancer research. Recent Res Devel Hum Pathol 1: $259-272,2003$. 
4. Kallioniemi A, Kallioniemi OP, Sudal D, et al: Comparative genomic hybridization for molecular cytogenetic analysis of solid tumors. Science 268: 818-821, 1992.

5. Pinkel D, Segraves R, Sudar D, et al: High resolution analysis of DNA copy number variation using comparative genomic hybridization to microarrays. Nature Genet 20: 207-211, 1998.

6. Aubele M, Zitzelsberger H, Schenck U, et al: Distinct cytogenetic alterations in squamous intraepithelial lesions of the cervix revealed by laser-assisted microdissection and comparative genomic hybridization. Cancer Cytopathol 84: 375-379, 1998.

7. Burki NG, Caduff $\mathrm{R}$, Walt $\mathrm{H}$, et al: Comparative genomic hybridization of the needle aspirates from breast carcinomas. Int J Cancer 88: 607-613, 2000.

8. Nagel H, Schulten HJ, Gunawan B, Brinck U and Fuzesi L: The potential value of comparative genomic hybridization analysis in effusion and fine needle aspiration cytology. Mod Pathol 15: 818-825, 2002.
9. Kitoh H, Ryozawa S, Harada T, et al: Comparative genomic hybridization analysis for pancreatic cancer specimens obtained by endoscopic ultraosnography-guided fine-needle aspiration. $\mathbf{J}$ Gastroentrol 40: 511-517, 2005.

10. Kawauchi S and Sasaki K: Comparative genomic hybridization for DNA extracted from cytological smear. Hum Pathol 36: 1241-1242, 2005.

11. Hirose Y, Aldape $\mathrm{K}$, Takahashi M, et al: Tissue microdissection and degenerate oligonucleotide primed-polymerase chain reaction (DOP-PCR) is an effective method to analyze genetic aberrations in invasive tumors. J Mol Diagn 3: 62-67, 2001.

12. Ikeda S, Kimura H, Honma E, Yokomizo S and Funakoshi N: Influence of mounting media on re-staining of cytology smears and DNA extraction. J Jpn Soc Clin Cytol 45: 73-76, 2006. 